\title{
Effect of temperature on development, survival, and adult body size of two green lacewings, Mallada desjardinsi and Chrysoperla nipponensis (Neuroptera: Chrysopidae)
}

\author{
Kengo NaKahira, * Ryoichi NaKahara and Ryo Arakawa \\ Laboratory of Applied Entomology, Faculty of Agriculture, Kochi University; Kochi 783-8502, Japan \\ (Received 25 November 2004; Accepted 12 July 2005)
}

\begin{abstract}
To search for a useful biological control agent and to determine the optimal rearing conditions for the green lacewings Mallada desjardinsi and Chrysoperla nipponensis, thermal effects on development, survival, and adult body size were examined at seven constant temperatures $\left(15.0,17.5,20.0,22.5,25.0,27.5\right.$, and $\left.30.0^{\circ} \mathrm{C}\right)$ with a photoperiod regime of $16 \mathrm{~L}: 8 \mathrm{D}(\mathrm{h})$. The developmental zero of $M$. desjardinsi larvae was higher than that of $C$. nipponensis larvae. The developmental zeros of $C$. carnea and $C$. nipponensis in earlier reports were similar to that of $C$. nipponensis in the present study. On the other hand, that of $M$. desjardinsi in earlier studies was somewhat higher than that of $M$. desjardinsi in the present study. A lower survival rate of $C$. nipponensis was observed in the cocoon stage at $15.0^{\circ} \mathrm{C}$. On the other hand, lower survival rates of $M$. desjardinsi were observed in the egg stage at $30.0^{\circ} \mathrm{C}$ and in the cocoon stage at 15.0 , 27.5 and $30.0^{\circ} \mathrm{C}$. The body size of both green lacewings was affected by temperature throughout the range tested. Smaller body sizes of $M$. desjardinsi and $C$. nipponensis adults were observed at $15.0,27.5$ and $30.0^{\circ} \mathrm{C}$. These results indicate that $C$. nipponensis has a wider optimum range of temperature for immature development than $M$. desjardinsi.
\end{abstract}

Key words: Developmental zero; thermal constant; optimum range of temperature; biological control agent

\section{INTRODUCTION}

The common green lacewings Mallada desjardinsi and Chrysoperla nipponensis are known to be important predators of many serious pests in Japan (Tsukaguchi, 1995). They are considered to be prospective candidates for biological control agents of aphids because of their high predatory capability (Niijima, 1997). There have been many reports on the life history and rearing method of both green lacewings (Wei et al., 1986; Kabissa et al., 1995, 1996; Kubota and Shiga, 1995; Nakamura et al., 2000; Niijima and Tokuno, 2000). However, there is little information available regarding thermal effects on development and survival (Liu, 1989; Fujiwara and Nomura, 1999). Temperature and photoperiod are principal environmental factors affecting the development, survival and diapause of insects. Thus, determining the thermal and photoperiodic effects on insects is useful for selection of biological control agents and for determination of their rearing conditions.

In the present study, the thermal effects on developmental period, survival rate, and adult body size of $M$. desjardinsi and $C$. nipponensis were examined to determine their resistance to low- and high-temperature regimes.

\section{MATERIALS AND METHODS}

Insect materials and culture techniques. Laboratory cultures of $M$. desjardinsi and $C$. nipponensis were established by female adults collected in Nankoku City $\left(33.5^{\circ} \mathrm{N}\right)$, Kochi Prefecture, Japan, in May 2003. The adults were individually reared in a plastic cup $(9.0 \mathrm{~cm}$ in diameter, $9.0 \mathrm{~cm}$ in depth) with moistened cotton and an artificial diet that was a mixture of yeast autolysate AY-65 (Asahi Food \& Healthcare Ltd.) and honey at a ratio of $1: 1$. The eggs laid were individually transferred to plastic petri dishes $(5.5 \mathrm{~cm}$ in diameter, $1.5 \mathrm{~cm}$ in depth). Newly hatched larvae were reared with de-

* To whom correspondence should be addressed at: E-mail: nakahira@cc.kochi-u.ac.jp DOI: $10.1303 / \mathrm{aez} .2005 .615$ 
frosted eggs of Ephestia kuehniella in the same plastic petri dish until adult emergence. All laboratory rearing was conducted under $16 \mathrm{~L}: 8 \mathrm{D}$ at $25.0 \pm 1.0^{\circ} \mathrm{C}$. The eggs and larvae of both green lacewings in the second and third generations were used for experiments.

Experiment 1. Eggs of both lacewings laid within $24 \mathrm{~h}$ were used for the experiment. Eggs were individually transferred to a 24-well microplate (each well $1.6 \mathrm{~cm}$ in diameter, $1.7 \mathrm{~cm}$ in depth) with a lid, and maintained under seven different temperature regimes of 15.0, 17.5, 20.0, $22.5,25.0,27.5$, and $30.0^{\circ} \mathrm{C}$ with $16 \mathrm{~L}: 8 \mathrm{D}$. Eggs that had not hatched within 2 mo from the start of the experiment as well as pupae within the cocoon that had not emerged within 2 mo were regarded as dead.

Experiment 2. First instar larvae of both green lacewings within $24 \mathrm{~h}$ of hatching were individually transferred to petri dishes $(5.5 \mathrm{~cm}$ in diameter, $1.5 \mathrm{~cm}$ in depth), and maintained under seven different temperature regimes of 15.0, 17.5, 20.0, $22.5,25.0,27.5$, and $30.0^{\circ} \mathrm{C}$ at $16 \mathrm{~L}: 8 \mathrm{D}$ until adult emergence. Adequate Ephestia kuehniella eggs to sustain development of both green lacewings' larvae were supplied as its prey. The dishes were inspected daily for the presence of the larval exuviae. The body weight and forewing length of adult green lacewings were measured within $24 \mathrm{~h}$ after emergence.

Data analyses. Developmental zero $\left(T_{0}\right)$ for egg, larva and cocoon stages were estimated from the simple regressions between velocities of development $(1 / D)$ and temperatures, and the thermal constant $(K)$ was similarly calculated from $T_{0}$ and the developmental period $(D)$. The effect of temperature on the developmental periods of egg, larva and cocoon stages of $M$. desjardinsi and $C$. nipponensis were analyzed using ANOVA (SPSS Inc., 2002). The effect of temperature on the forewing length and body weight of $M$. desjardinsi and $C$. nipponensis were also analyzed using ANOVA (SPSS Inc., 2002). The significance of differences in the forewing length and body weight of $M$. desjardinsi and $C$. nipponensis at each temperature were analyzed among the seven constant temperatures based on the 5\% level of the Bonferroni's multiple comparison test (SPSS Inc., 2002). The significance of differences in the arcsin-root transformed survival rates of egg, larva, and cocoon stages of $M$. des-
Table 1. Developmental period of egg stages of

$M$. desjardinsi and $C$. nipponensis at seven constant temperatures with $16 \mathrm{~L}: 8 \mathrm{D}$

\begin{tabular}{crrrr}
\hline \multirow{2}{*}{$\begin{array}{c}\text { Temperature } \\
\left({ }^{\circ} \mathrm{C}\right)\end{array}$} & \multicolumn{4}{c}{ Developmental period of egg stage $(\mathrm{d})$} \\
\cline { 2 - 5 } & $n^{\mathrm{a}}$ & M. desjardinsi $^{\mathrm{b}}$ & $n^{\mathrm{a}}$ & C. nipponensis $^{\mathrm{b}}$ \\
\hline 15.0 & 30 & $12.3 \pm 0.6$ & 23 & $13.6 \pm 0.7$ \\
17.5 & 31 & $8.6 \pm 0.6$ & 22 & $10.3 \pm 0.5$ \\
20.0 & 31 & $7.0 \pm 0.4$ & 26 & $7.6 \pm 0.6$ \\
22.5 & 33 & $5.4 \pm 0.5$ & 26 & $6.2 \pm 0.5$ \\
25.0 & 29 & $5.0 \pm 0.2$ & 26 & $5.0 \pm 0.0$ \\
27.5 & 28 & $4.0 \pm 0.2$ & 24 & $4.6 \pm 0.5$ \\
30.0 & 11 & $3.8 \pm 0.4$ & 18 & $4.1 \pm 0.2$ \\
$F^{\mathrm{c}}$ & & $1,243.418$ & & $1,192.851$ \\
$\mathrm{df}^{\mathrm{c}}$ & \multicolumn{5}{c}{} & 6 \\
$p^{\mathrm{c}}$ & $<0.001$ & & $<0.001$ \\
\hline
\end{tabular}

${ }^{\text {a }}$ Number of eggs hatched.

${ }^{\mathrm{b}}$ Data indicate the mean \pm SD.

${ }^{\mathrm{c}}$ Results of ANOVA.

jardinsi and $C$. nipponensis at each temperature were analyzed among the seven constant temperatures based on the 5\% level of the Tukey-type multiple comparison test after the 5\% level of the Chisquare test (Zar, 1999).

\section{RESULTS AND DISCUSSION}

The developmental periods of egg, larvae and cocoon stages of $M$. desjardinsi and $C$. nipponensis were significantly affected by temperatures from 15.0 to $30.0^{\circ} \mathrm{C}$ (Tables 1,2 , and $3 ; p<0.05$, ANOVA). The same developmental period was observed in the cocoon stage of $M$. desjardinsi at 15.0 and $17.5^{\circ} \mathrm{C}$ (Table 3). For this reason, the data at $15.0^{\circ} \mathrm{C}$ for this species were excluded from the calculation of developmental zeros and thermal constants. Regression equations between the velocities of development and temperatures, developmental zeros and thermal constants for $M$. desjardinsi and C. nipponensis are shown in Table 4.

Determining the developmental zero of potential biological control agents is useful for the estimation of their available seasons, as it shows the minimum temperature required for development (Kiritani, 1997). The larval developmental zeros of $M$. desjardinsi and $C$. nipponensis are especially useful in comparing their performance as biological control agents, as they prey on pests at the larval stage only (Niijima, 1997). Because of the higher 
Table 2. Developmental period of the larval stage of M. desjardinsi and C. nipponensis at seven constant temperatures with $16 \mathrm{~L}: 8 \mathrm{D}$

\begin{tabular}{|c|c|c|c|c|c|c|c|c|}
\hline \multirow{3}{*}{$\begin{array}{c}\text { Temperature } \\
\left({ }^{\circ} \mathrm{C}\right)\end{array}$} & \multicolumn{8}{|c|}{ Developmental period of larval stage (d) } \\
\hline & \multicolumn{4}{|c|}{ Male } & \multicolumn{4}{|c|}{ Female } \\
\hline & $n^{\mathrm{a}}$ & M. desjardinsi ${ }^{\mathrm{b}}$ & $n^{\mathrm{a}}$ & C. nipponensis ${ }^{\mathrm{b}}$ & $n^{\mathrm{a}}$ & M. desjardinsi $i^{\mathrm{b}}$ & $n^{\mathrm{a}}$ & C. nipponensis ${ }^{\mathrm{b}}$ \\
\hline 15.0 & 9 & $24.5 \pm 2.3$ & 12 & $24.7 \pm 1.8$ & 13 & $24.2 \pm 0.8$ & 16 & $25.0 \pm 1.9$ \\
\hline 17.5 & 13 & $17.5 \pm 1.3$ & 22 & $16.5 \pm 1.0$ & 19 & $17.0 \pm 0.9$ & 18 & $18.1 \pm 1.9$ \\
\hline 20.0 & 6 & $12.5 \pm 1.6$ & 17 & $12.9 \pm 1.0$ & 24 & $12.9 \pm 1.5$ & 21 & $12.8 \pm 0.8$ \\
\hline 22.5 & 12 & $9.8 \pm 0.7$ & 18 & $10.2 \pm 0.6$ & 22 & $9.4 \pm 0.6$ & 22 & $10.4 \pm 0.8$ \\
\hline 25.0 & 14 & $7.6 \pm 0.8$ & 17 & $9.3 \pm 1.0$ & 16 & $7.8 \pm 0.9$ & 15 & $9.6 \pm 1.0$ \\
\hline 27.5 & 8 & $6.4 \pm 0.5$ & 17 & $7.2 \pm 0.8$ & 21 & $7.0 \pm 0.6$ & 23 & $7.4 \pm 0.7$ \\
\hline 30.0 & 7 & $5.9 \pm 0.4$ & 19 & $6.4 \pm 0.6$ & 9 & $5.8 \pm 0.4$ & 14 & $6.9 \pm 0.6$ \\
\hline$F^{\mathrm{c}}$ & & 287.530 & & 692.447 & & 728.609 & & 588.967 \\
\hline $\mathrm{df}^{\mathrm{c}}$ & & 6 & & 6 & & 6 & & 6 \\
\hline$p^{\mathrm{c}}$ & & $<0.001$ & & $<0.001$ & & $<0.001$ & & $<0.001$ \\
\hline
\end{tabular}

${ }^{a}$ Number of larvae that spun a cocoon.

${ }^{\mathrm{b}}$ Data indicate the mean \pm SD.

${ }^{\mathrm{c}}$ Results of ANOVA.

Table 3. Developmental period of the cocoon stage of $M$. desjardinsi and C. nipponensis at seven constant temperatures with $16 \mathrm{~L}: 8 \mathrm{D}$

\begin{tabular}{|c|c|c|c|c|c|c|c|c|}
\hline \multirow{3}{*}{$\begin{array}{c}\text { Temperature } \\
\left({ }^{\circ} \mathrm{C}\right)\end{array}$} & \multicolumn{8}{|c|}{ Developmental periods of cocoon stage (d) } \\
\hline & \multicolumn{4}{|c|}{ Male } & \multicolumn{4}{|c|}{ Female } \\
\hline & $n^{\mathrm{a}}$ & M. desjardinsi $i^{\mathrm{b}}$ & $n^{\mathrm{a}}$ & C. nipponensis ${ }^{\mathrm{b}}$ & $n^{\mathrm{a}}$ & M. desjardinsi ${ }^{\mathrm{b}}$ & $n^{\mathrm{a}}$ & C. nipponensis ${ }^{\mathrm{b}}$ \\
\hline 15.0 & 9 & $23.9 \pm 2.5$ & 12 & $27.8 \pm 1.2$ & 13 & $23.5 \pm 1.2$ & 16 & $28.7 \pm 1.9$ \\
\hline 17.5 & 13 & $23.9 \pm 1.9$ & 22 & $18.9 \pm 1.3$ & 19 & $24.3 \pm 1.4$ & 18 & $18.9 \pm 1.3$ \\
\hline 20.0 & 6 & $17.7 \pm 1.0$ & 17 & $15.0 \pm 1.8$ & 24 & $18.8 \pm 1.7$ & 21 & $15.0 \pm 1.8$ \\
\hline 22.5 & 12 & $14.3 \pm 1.2$ & 18 & $11.4 \pm 0.8$ & 22 & $14.6 \pm 1.0$ & 22 & $11.4 \pm 0.8$ \\
\hline 25.0 & 14 & $12.1 \pm 0.5$ & 17 & $10.1 \pm 0.7$ & 16 & $12.6 \pm 0.9$ & 15 & $10.1 \pm 0.7$ \\
\hline 27.5 & 8 & $10.8 \pm 0.5$ & 17 & $9.7 \pm 1.3$ & 21 & $10.9 \pm 0.9$ & 23 & $9.7 \pm 1.3$ \\
\hline 30.0 & 7 & $10.0 \pm 0.0$ & 19 & $7.9 \pm 0.8$ & 9 & $10.2 \pm 0.4$ & 14 & $7.9 \pm 0.8$ \\
\hline$F^{\mathrm{c}}$ & & 184.022 & & 449.138 & & 375.526 & & 442.847 \\
\hline $\mathrm{df}^{\mathrm{c}}$ & & 6 & & 6 & & 6 & & 6 \\
\hline$p^{\mathrm{c}}$ & & $<0.001$ & & $<0.001$ & & $<0.001$ & & $<0.001$ \\
\hline
\end{tabular}

${ }^{\mathrm{a}}$ Number of cocoons emerged.

${ }^{\mathrm{b}}$ Data indicate the mean \pm SD.

${ }^{\mathrm{c}}$ Results of ANOVA.

larval developmental zero of $M$. desjardinsi (Table 4), one would expect that its active period in the winter season is shorter than that of C. nipponensis.

Although $C$. nipponensis was treated as synonymous with $C$. carnea by Tsukaguchi (1985), the Japanese C. carnea was later revised to C. nipponensis because the colors of the adult wing grate cross veins are green in $C$. carnea but black in $C$. nipponensis (Brooks, 1994). There is a wealth of developmental zero information for $C$. carnea but very little for $C$. nipponensis. The developmental zero of C. carnea was $9.5^{\circ} \mathrm{C}$ in a New York population, $9.8^{\circ} \mathrm{C}$ in an Alaskan population, $10.5^{\circ} \mathrm{C}$ in a Mexican population, and about $10^{\circ} \mathrm{C}$ in a Russian population (Tauber and Tauber, 1982; Volkovich, 
Table 4. Regression equation between the velocity of development and temperature, developmental zero, and thermal constant for M. desjardinsi and C. nipponensis

\begin{tabular}{|c|c|c|c|c|c|c|}
\hline Stage & Species & Sex & Regression equation $^{\mathrm{ab}}$ & $R^{2}$ & $\begin{array}{l}\text { Developmental } \\
\text { zero }\left({ }^{\circ} \mathrm{C}\right)^{\mathrm{b}}\end{array}$ & $\begin{array}{l}\text { Thermal constant } \\
(K){\text { (degree-d })^{\mathrm{b}}}^{\text {deg }}\end{array}$ \\
\hline \multirow[t]{2}{*}{ Egg } & M. desjardinsi & & $Y=0.0123 X-0.0994$ & 0.9841 & 8.1 & 80.5 \\
\hline & C. nipponensis & & $Y=0.0119 X-0.1067$ & 0.9953 & 9.0 & 83.8 \\
\hline \multirow[t]{4}{*}{ Larva } & M. desjardinsi & $\hat{0}$ & $Y=0.0095 X-0.1084$ & 0.9930 & 11.4 & 106.3 \\
\hline & & o & $Y=0.0091 X-0.1009$ & 0.9938 & 11.1 & 110.7 \\
\hline & C. nipponensis & $\hat{\sigma}$ & $Y=0.0077 X-0.0755$ & 0.9919 & 9.8 & 130.7 \\
\hline & & 우 & $Y=0.0072 X-0.0674$ & 0.9885 & 9.4 & 140.5 \\
\hline \multirow[t]{4}{*}{ Cocoon } & M. desjardinsi & $\hat{0}$ & $Y=0.0047 X-0.0376$ & 0.9859 & 8.0 & 213.5 \\
\hline & & q & $Y=0.0047 X-0.0392$ & 0.9872 & 8.3 & 214.0 \\
\hline & C. nipponensis & $\hat{\sigma}$ & $Y=0.0059 X-0.0499$ & 0.9864 & 8.5 & 171.8 \\
\hline & & q & $Y=0.0056 X-0.0452$ & 0.9854 & 8.1 & 180.1 \\
\hline
\end{tabular}

${ }^{\text {a }} X$ and $Y$ indicate the temperature and developmental rate $(1 / D)$, respectively.

${ }^{\mathrm{b}}$ Regression equation or values for $M$. desjardinsi and C. nipponensis at each stage were calculated based on the data from 17.5 to $30.0^{\circ} \mathrm{C}$ and from 15.0 to $30.0^{\circ} \mathrm{C}$, respectively.

1998). The developmental zero of C. nipponensis (Chiba population) was $10.2^{\circ} \mathrm{C}$ (Fujiwara and Nomura, 1999). These developmental zeros of $C$. carnea and $C$. nipponensis were similar to that of C. nipponensis in the present study (Table 4). The developmental zero of Chinese $M$. desjardinsi (Guandongs population) was $12.4^{\circ} \mathrm{C}$ for egg stage and $13.7^{\circ} \mathrm{C}$ for larval stage (Liu, 1989). These values are somewhat higher than that of $M$. desjardinsi in the present study (Table 4). Therefore, the population of $M$. desjardinsi in this study can generally develop under lower thermal conditions than the Guandongs population of $M$. desjardinsi.

In the present study, a low egg survival rate (20.8-68.8\%) was observed in second and third generations of $M$. desjardinsi and $C$. nipponensis at all temperature examined (Table 5). Kubota and Shiga (1995) reported that the rearing for successive generations of the green lacewing led to lower egg survival rates in the later generations. Improvement of the rearing method for adult green lacewings is necessary for establishing a more efficient rearing system.

A lower survival rate of $C$. nipponensis was observed in the cocoon stage at $15.0^{\circ} \mathrm{C}$ (Tables 5,6 , and $7 ; p<0.05$, Tukey-type multiple comparison test). On the other hand, lower survival rates of $M$. desjardinsi were observed in the egg stage at $30.0^{\circ} \mathrm{C}$ and in the cocoon stage at $15.0,27.5$ and $30.0^{\circ} \mathrm{C}$ (Tables 5, 6, and 7; $p<0.05$, Tukey-type multiple comparison test). The body size of both green lacewings was affected by temperatures of
Table 5. Survival rate of egg stage of M. desjardinsi and C. nipponensis at seven constant temperatures with $16 \mathrm{~L}: 8 \mathrm{D}$

\begin{tabular}{ccc}
\hline \multirow{2}{*}{$\begin{array}{c}\text { Temperature } \\
\left({ }^{\circ} \mathrm{C}\right)\end{array}$} & \multicolumn{2}{c}{ Survival rate of egg stage (\%) } \\
\cline { 2 - 3 } & M. desjardinsi ${ }^{\mathrm{a}}$ & C. nipponensis $^{\mathrm{a}}$ \\
\hline 15.0 & $62.5 \mathrm{a}$ & $47.9 \mathrm{a}$ \\
17.5 & $64.6 \mathrm{a}$ & $45.8 \mathrm{a}$ \\
20.0 & $64.6 \mathrm{a}$ & $54.2 \mathrm{a}$ \\
22.5 & $68.8 \mathrm{a}$ & $54.2 \mathrm{a}$ \\
25.0 & $60.4 \mathrm{a}$ & $54.2 \mathrm{a}$ \\
27.5 & $58.3 \mathrm{a}$ & $50.0 \mathrm{a}$ \\
30.0 & $20.8 \mathrm{~b}$ & $37.5 \mathrm{a}$ \\
\hline
\end{tabular}

${ }^{a}$ Number of eggs tested was 48 at each temperature. Percentages in a given column followed by the same letter are not significantly different at the 5\% level (Tukey-type multiple comparison test).

$15.0^{\circ} \mathrm{C}$ to $30.0^{\circ} \mathrm{C}$ (Tables 8 and 9; $p<0.05$, ANOVA). Smaller adult body sizes were observed in $M$. desjardinsi and $C$. nipponensis at 15.0, 27.5 and $30.0^{\circ} \mathrm{C}$. (Tables 8 and 9; $p<0.05$, Bonferroni's multiple comparison test). The lower survival rate of immature development and smaller adult body size indicate the possible growth inhibition in highand/or low-temperature regimes during the immature stages of $M$. desjardinsi and $C$. nipponensis. Therefore, the growth inhibition of immature development was severe in $M$. desjardinsi at 15.0 , 27.5 and $30.0^{\circ} \mathrm{C}$, and in C. nipponensis at $30.0^{\circ} \mathrm{C}$, but it is slight in $C$. nipponensis at 15.0 and $27.5^{\circ} \mathrm{C}$.

In this study, the thermal effects were examined 
Table 6. Survival rate of the larval stage of $M$. desjardinsi and $C$. nipponensis at seven constant temperatures with $16 \mathrm{~L}: 8 \mathrm{D}$

\begin{tabular}{ccccc}
\hline \multirow{2}{*}{$\begin{array}{c}\text { Temperature } \\
\left({ }^{\circ} \mathrm{C}\right)\end{array}$} & \multicolumn{4}{c}{ Survival rate of larval stage (\%) } \\
\cline { 2 - 5 } & $n^{\mathrm{a}}$ & M. desjardinsi ${ }^{\mathrm{b}}$ & $n^{\mathrm{a}}$ & C. nipponensis $^{\mathrm{b}}$ \\
\hline 15.0 & 42 & $69.1 \mathrm{a}$ & 48 & $72.9 \mathrm{a}$ \\
17.5 & 43 & $79.1 \mathrm{a}$ & 50 & $88.0 \mathrm{a}$ \\
20.0 & 45 & $73.3 \mathrm{a}$ & 50 & $82.0 \mathrm{a}$ \\
22.5 & 45 & $82.2 \mathrm{a}$ & 50 & $84.0 \mathrm{a}$ \\
25.0 & 45 & $68.9 \mathrm{a}$ & 50 & $80.0 \mathrm{a}$ \\
27.5 & 45 & $80.0 \mathrm{a}$ & 50 & $84.0 \mathrm{a}$ \\
30.0 & 45 & $66.7 \mathrm{a}$ & 50 & $90.0 \mathrm{a}$ \\
\hline
\end{tabular}

${ }^{a}$ Number of larvae examined.

${ }^{\mathrm{b}}$ Percentages in a given column followed by the same letter are not significantly different at the $5 \%$ level (Tukey-type multiple comparison test).
Table 7. Survival rate of the cocoon stage of $M$. desjardinsi and $C$. nipponensis at seven constant temperatures with $16 \mathrm{~L}: 8 \mathrm{D}$

\begin{tabular}{ccccc}
\hline \multirow{2}{*}{$\begin{array}{c}\text { Temperature } \\
\left({ }^{\circ} \mathrm{C}\right)\end{array}$} & \multicolumn{4}{c}{ Survival rate of cocoon stage (\%) } \\
\cline { 2 - 5 } & $n^{\mathrm{a}}$ & M. desjardinsi ${ }^{\mathrm{b}}$ & $n^{\mathrm{a}}$ & C. nipponensis $^{\mathrm{b}}$ \\
\hline 15.0 & 29 & $75.9 \mathrm{~b}$ & 35 & $80.0 \mathrm{ab}$ \\
17.5 & 34 & $94.1 \mathrm{a}$ & 44 & $90.9 \mathrm{ab}$ \\
20.0 & 33 & $90.9 \mathrm{a}$ & 41 & $92.7 \mathrm{ab}$ \\
22.5 & 37 & $91.9 \mathrm{a}$ & 42 & $95.2 \mathrm{a}$ \\
25.0 & 31 & $96.8 \mathrm{a}$ & 40 & $80.0 \mathrm{ab}$ \\
27.5 & 36 & $80.6 \mathrm{~b}$ & 42 & $95.2 \mathrm{a}$ \\
30.0 & 30 & $53.3 \mathrm{~b}$ & 45 & $68.9 \mathrm{~b}$ \\
\hline
\end{tabular}

${ }^{a}$ Number of cocoons examined.

${ }^{b}$ Percentages in a given column followed by the same letter are not significantly different at the $5 \%$ level (Tukey-type multiple comparison test).

Table 8. Forewing length of emerged $M$. desjardinsi and C. nipponensis at seven constant temperatures with $16 \mathrm{~L}: 8 \mathrm{D}$

\begin{tabular}{|c|c|c|c|c|c|c|c|c|}
\hline \multirow{3}{*}{$\begin{array}{c}\text { Temperature } \\
\left({ }^{\circ} \mathrm{C}\right)\end{array}$} & \multicolumn{8}{|c|}{ Forewing length $(\mathrm{mm})$} \\
\hline & \multicolumn{4}{|c|}{ Male } & \multicolumn{4}{|c|}{ Female } \\
\hline & $n^{\mathrm{a}}$ & M. desjardinsi ${ }^{\mathrm{b}}$ & $n^{\mathrm{a}}$ & C. nipponensis ${ }^{\mathrm{b}}$ & $n^{\mathrm{a}}$ & M. desjardinsi ${ }^{\mathrm{b}}$ & $n^{\mathrm{a}}$ & C. nipponensis ${ }^{\mathrm{b}}$ \\
\hline 15.0 & 9 & $12.3 \pm 0.6 \mathrm{ab}$ & 12 & $12.0 \pm 0.4 \mathrm{ab}$ & 13 & $13.2 \pm 0.6 \mathrm{bc}$ & 16 & $12.5 \pm 0.5 \mathrm{abc}$ \\
\hline 17.5 & 13 & $12.5 \pm 0.4 \mathrm{ab}$ & 22 & $12.1 \pm 0.6 \mathrm{a}$ & 19 & $13.5 \pm 0.4 \mathrm{ab}$ & 18 & $13.1 \pm 0.3 \mathrm{a}$ \\
\hline 20.0 & 6 & $12.6 \pm 0.2 \mathrm{ab}$ & 17 & $12.3 \pm 0.4 \mathrm{a}$ & 24 & $13.6 \pm 0.3 \mathrm{a}$ & 21 & $13.0 \pm 0.4 \mathrm{ab}$ \\
\hline 22.5 & 12 & $12.7 \pm 0.2 \mathrm{a}$ & 18 & $12.0 \pm 0.3 \mathrm{ab}$ & 22 & $13.7 \pm 0.5 \mathrm{a}$ & 22 & $12.6 \pm 0.7 \mathrm{ab}$ \\
\hline 25.0 & 14 & $12.6 \pm 0.4 \mathrm{ab}$ & 17 & $11.6 \pm 0.5 \mathrm{bc}$ & 16 & $13.7 \pm 0.4 \mathrm{ab}$ & 15 & $12.8 \pm 0.6 \mathrm{ab}$ \\
\hline 27.5 & 8 & $12.3 \pm 0.2 \mathrm{ab}$ & 17 & $11.5 \pm 0.6 \mathrm{bc}$ & 21 & $13.3 \pm 0.3 \mathrm{ac}$ & 23 & $12.5 \pm 0.5 \mathrm{bc}$ \\
\hline 30.0 & 7 & $12.1 \pm 0.5 \mathrm{~b}$ & 19 & $11.2 \pm 0.6 \mathrm{c}$ & 9 & $12.8 \pm 0.4 \mathrm{c}$ & 14 & $12.1 \pm 0.6 \mathrm{c}$ \\
\hline$F^{\mathrm{c}}$ & & 2.741 & & 11.489 & & 7.938 & & 8.007 \\
\hline$d f^{c}$ & & 6 & & 6 & & 6 & & 6 \\
\hline$p^{\mathrm{c}}$ & & 0.020 & & $<0.001$ & & $<0.001$ & & $<0.001$ \\
\hline
\end{tabular}

${ }^{\mathrm{a}}$ Number of adults examined.

${ }^{\mathrm{b}}$ Data indicate the mean \pm SD. Values in a given column followed by the same letter are not significantly different at the $5 \%$ level (Bonferroni's multiple comparison test).

${ }^{\mathrm{c}}$ Results of ANOVA.

in M. desjardinsi and C. nipponensis to search for useful biological control agents and to determine their optimal rearing conditions. C. nipponensis had a wider optimum range of temperature for immature development than $M$. desjardinsi. Photoperiodic response of $M$. desjardinsi and $C$. nipponensis is also useful to evaluate their performance as biological control agents. The effect of the photoperiod on the two green lacewings should be in- vestigated before determining their performance in greenhouses and fields.

\section{ACKNOWLEDGEMENTS}

The authors would like to thank Dr. S. Tsukaguchi, Dr. K. Nosato, Dr. O. A. Dasilao, Mr. Y. Matsuo and Mr. Y. Sawada. This study was supported in part by a Grant-in-Aid from the Japan Society for Promotion of Science (no. 15208007). 
Table 9. Body weight of emerged $M$. desjardinsi and C. nipponensis at seven constant temperatures with 16L:8D

\begin{tabular}{|c|c|c|c|c|c|c|c|c|}
\hline \multirow{3}{*}{$\begin{array}{c}\text { Temperature } \\
\left({ }^{\circ} \mathrm{C}\right)\end{array}$} & \multicolumn{8}{|c|}{ Body weight (mg) } \\
\hline & \multicolumn{4}{|c|}{ Male } & \multicolumn{4}{|c|}{ Female } \\
\hline & $n^{\mathrm{a}}$ & M. desjardinsi ${ }^{\mathrm{b}}$ & $n^{\mathrm{a}}$ & C. nipponensis ${ }^{\mathrm{b}}$ & $n^{\mathrm{a}}$ & M. desjardinsi ${ }^{\mathrm{b}}$ & $n^{\mathrm{a}}$ & C. nipponensis ${ }^{\mathrm{b}}$ \\
\hline 15.0 & 9 & $6.1 \pm 1.2 \mathrm{bc}$ & 12 & $5.4 \pm 0.5 \mathrm{abc}$ & 13 & $8.0 \pm 1.1 \mathrm{abc}$ & 16 & $6.6 \pm 0.7 \mathrm{bc}$ \\
\hline 17.5 & 13 & $6.9 \pm 0.7 \mathrm{ac}$ & 22 & $5.8 \pm 0.8 \mathrm{a}$ & 19 & $8.2 \pm 0.6 \mathrm{ab}$ & 18 & $7.2 \pm 0.6 \mathrm{ab}$ \\
\hline 20.0 & 6 & $7.2 \pm 0.3 \mathrm{ab}$ & 17 & $5.8 \pm 0.5 \mathrm{a}$ & 24 & $8.2 \pm 0.8 \mathrm{ab}$ & 21 & $7.0 \pm 0.4 \mathrm{ab}$ \\
\hline 22.5 & 12 & $7.1 \pm 0.8 \mathrm{ab}$ & 18 & $5.7 \pm 0.7 \mathrm{ab}$ & 22 & $8.4 \pm 0.6 \mathrm{a}$ & 22 & $7.2 \pm 0.7 \mathrm{ab}$ \\
\hline 25.0 & 14 & $7.3 \pm 0.7 \mathrm{a}$ & 17 & $5.6 \pm 0.9 \mathrm{ab}$ & 16 & $8.3 \pm 0.3 \mathrm{ab}$ & 15 & $7.7 \pm 1.4 \mathrm{a}$ \\
\hline 27.5 & 8 & $6.4 \pm 0.5 \mathrm{ac}$ & 17 & $5.0 \pm 0.5 \mathrm{bc}$ & 21 & $7.7 \pm 0.6 \mathrm{bd}$ & 23 & $6.6 \pm 0.6 \mathrm{bc}$ \\
\hline 30.0 & 7 & $5.8 \pm 0.9 \mathrm{c}$ & 19 & $4.6 \pm 0.7 \mathrm{c}$ & 9 & $7.1 \pm 1.0 \mathrm{~cd}$ & 14 & $6.1 \pm 0.8 \mathrm{c}$ \\
\hline$F^{\mathrm{c}}$ & & 4.609 & & 10.325 & & 5.163 & & 7.176 \\
\hline $\mathrm{df}^{\mathrm{c}}$ & & 6 & & 6 & & 6 & & 6 \\
\hline$p^{\mathrm{c}}$ & & 0.001 & & $<0.001$ & & $<0.001$ & & $<0.001$ \\
\hline
\end{tabular}

${ }^{a}$ Number of adults examined.

${ }^{\mathrm{b}}$ Data indicate the mean \pm SD. Values in a given column followed by the same letter are not significantly different at the $5 \%$ level (Bonferroni's multiple comparison test).

${ }^{\mathrm{c}}$ Results of ANOVA.

\section{REFERENCES}

Brooks, S. J. (1994) A taxonomic review of the common green lacewing genus Chrysoperla (Neuroptera: Chrysopidae). Bull. Br. Nat. Hist. (Ent.) 63: 137-210.

Fujiwara, C. and M. Nomura (1999) Effects of photoperiod and temperature on larval development of Chrysoperla carnea Stephens (Neuroptera: Chrysopidae). Jpn. J. Appl. Entomol. Zool. 43: 175-179 (in Japanese with English summary).

Kabissa, J. C., H. Y. Kayumbo and J. G. Yarro (1995) Comparative biology of Mallada desjardinsi (Navas) and Chrysoperla congrua (Walker) (Neuroptera: Chrysopidae), predators of Helicoverpa armigera (Hubner) (Lepidptera: Noctuidae) and Aphis gossypii (Glover) (Homoptera: Aphididae) on cotton in eastern Tanzania. Int. J. Pest Manage. 41: 214-218.

Kabissa, J. C., H. Y. Kayumbo and J. G. Yarro (1996) Seasonal abundance of chrysopids (Neuroptera: Chrysopidae) preying on Helicoverpa armigera (Hubner) (Lepidptera: Noctuidae) and Aphis gossypii (Glover) (Homoptera: Aphididae) on cotton in eastern Tanzania. Crop Prot. 15: 5-8.

Kiritani, K. (1997) The low development threshold temperature and the thermal constant in insects, mites and nematodes in Japan. Misc. Publ. Natl. Inst. Agro-Environ. Sci. 21: 1-72 (in Japanese with English summary).

Kubota, T. and M. Shiga (1995) Successive mass rearing of chrysopids (Neuroptera: Chrysopidae) on eggs of Tribolium castaneum (Coleoptera: Tenebrionidae). Jpn. J. Appl. Entomol. Zool. 39: 51-58 (in Japanese with English summary).

Liu, Z. (1989) Studies on the interaction system of citrus psylla, Diaphorina citri Kuw. and its natural enemies, Tetrastichus sp. and Chrysopa boninensis Okamoto. In Studies on the Integrated Management of Citrus Insect
Pests (M. Huang ed.). Academic Book and Periodical Press, Guangdong, pp. 144-164.

Nakamura, M., H. Nemoto and H. Amano (2000) Ovipositional characteristics of lacewings, Chrysoperla carnea (Stephans) and Chrysopa pallens (Rambur) (Neuroptera: Chrysopidae) in field. Jpn. J. Appl. Entomol. Zool. 44: 17-26 (in Japanese with English summary).

Niijima, K. (1997) Rearing methods of native natural enemies in Japan: Native chrysopids. Plant Prot. 51: 526529 (in Japanese).

Niijima, K and J. Tokuno (2000) Fecundity of several species of Japanese lacewing and their thermal and dietary effects. Bull. Fac. Agric. Tamagawa Univ. 40: 113 (in Japanese with English summary).

SPSS Inc. (2002) SPSS 11.5J for Windows. SPSS Inc., Chicago, U.S.A.

Tauber, C. A. and M. J. Tauber (1982) Evolution of seasonal adaptations and life history traits in Chrysopa: response to diverse selective pressures. In Evolution and Genetics of Life Histories (H. Dingle and J. P. Hegmann eds.). Springer, New York, pp. 51-72.

Tsukaguchi, S. (1985) A check list of published species of Japanese Chrysopidae (Neuroptera). Kontyû 53: 503506.

Tsukaguchi, S. (1995) Chrysopidae of Japan. Yutaka Insatsu Co., Osaka. 223 pp.

Volkovich, T. A. (1998) Environmental control of seasonal cycles in green lacewings (Neuroptera: Chrysopidae) from forest-steppe zone of Russia. Acta Zool. Fenn. 209: 263-275.

Wei, C., B. Huang and C. Guo (1986) Studies on Chrysopa boninensis Okamoto in Guangzhou. Acta Entomol. Sin. 29: 174-180 (in Chinese with English summary).

Zar, J. H. (1999) Biostatistical Analysis. Fourth ed. Prentice Hall International, London. 663 pp. 